Jurnal Ilmiah Akuntansi Universitas Pamulang

Vol. 8, No. 2, Juli 2020

ISSN 2599-1922

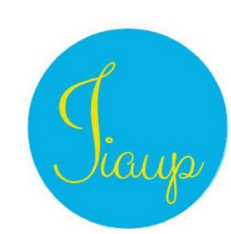

Received : 17 Januari 2020 Revised: 20 April 2020 Accepted: 22 Juni 2020 Published :31 Juli 2020

\title{
PENGARUH INFLASI, BI RATE, SUKU BUNGA KREDIT UMKM TERHADAP NON PERFORMING LOAN KREDIT UMKM PADA BANK UMUM
}

\author{
SUHARNA \\ Prodi Akuntansi S1, Fakultas Ekonomi, Universitas Pamulang \\ Email: suharno.hadisumarso@gmail.com
}

\begin{abstract}
This study aims to obtain empirical evidence on the influence of inflation, rate of Bank Indonesia, and credit interest rate on non-performing SMEs credit loan at Commercial Banks. This study uses secondary data obtained from quarterly OJK reports and Bank Indonesia monthly reports for the period of 2014 - 2018. Multiple linear regression models are used to test the hypotheses of this study. It was found that the inflation rate and the rate of Bank Indonesia individually doesn't have a siignificant influence on non-performing SMEs credit loans. On the other hand, it was found that credit interest rate has a signifinicant influence on non - performing SMEs credit loans.
\end{abstract}

Keywords: Inflantion, BI Rate, Credit Interest Rate, non - performing SMEs credit loans

\section{PENDAHULUAN}

Total Kredit UMKM per 31 Desember 2013 sebesar Rp 608.823,41 milyar naik menjadi sebesar Rp 969.972,00 milyar pada bulan Desember 2018 atau meningkat sebesar Rp 361.148,59 milyar (59,32\%). Dari jumlah tersebut masingmasing diberikan oleh Bank Persero (Pemerintah) sebesar Rp 551.935,00 milyar (56,90\%), Bank Swasta Nasional sebesar Rp 338.455,00 milyar (34,89\%), Bank Pembangunan Daerah sebesar Rp 70.089,00 milyar (7,23\%) dan Bank Campuran \& Asing sebesar Rp 9.943,00 milyar, dengan kata lain pemberian kredit UMKM selama ini didominasi oleh Bank Persero (Pemerintah).

Non Performing Loan (NPL) kredit UMKM Bank Umum, secara nominal mengalami peningkatan yaitu dari Rp 19.515,49 milyar pada bulan Desember 2013 menjadi Rp 32.421,00 milyar pada Desember 2018 atau meningkat sebesar Rp 12.905,51 milyar (66,13\%). Secara nominal komposisi NPL kredit UMKM terbesar berasal dari Bank Persero (Pemerintah) sebesar Rp 13.988,00 milyar, Bank Swasta Nasional sebesar Rp 11.892,00 milyar (36,68\%), Bank Pembangunan Daerah sebesar Rp 5.603,00 milyar (17,28\%) dan Bank Campuran \& Asing sebesar Rp 928,00 milyar $(2,86 \%)$.

Rata-rata NPL Kredit UMKM Bank Umum selama periode Maret 2014 sampai dengan Desember 2018 sebesar 4,37\%. Total NPL Kredit UMKM pada 
posisi 31 Desember 2018 sebesar 3,34\% dan jumlah tersebut masih di bawah ketentuan Bank Indonesia (OJK) yaitu sebesar 5\%. Bila dilihat dari total nilai NPL Kredit UMKM permasing-masing bank, terdapat 2 kelompok bank yang NPLnya melebihi ketentuan Bank Indonesia (OJK), yaitu kelompok bank campuran \& asing sebesar 9,78\% dan Bank Pembangunan Daerah sebesar 7,99\%. Sedangkan NPL Kredit UMKM untuk bank swasta nasional sebesar 3,51\% dan bank persero (Pemerintah) sebesar 2,54\%. Kondisi demikian mencerminkan bahwa risiko Kredit UMKM terbesar dialami oleh bank campuran, asing dan Bank Pembangunan Daerah, sedangkan risiko kredit UMKM yang paling kecil adalah kredit UMKM yang diberikan oleh bank persero (pemerintah) yaitu sebesar 2,54\%.

Tingginya NPL Kredit UMKM secara umum disebabkan oleh faktor mikro dan makro ekonomi seperti inflasi, suku bunga (BI rate) dan suku bunga pinjaman. Peningkatan inflasi, secara umum akan berdampak terhadap penurunan daya beli masyarakat sehingga secara tidak langsung akan berpengaruh terhadap kemampuan membayar debitur kepada pihak bank. Selain inflasi, peningkatan suku bunga pinjaman juga akan berdampak terhadap peningkatan jumlah angsuran/bunga pinjaman yang harus dibayar debitur, apabila pendapatan tetap atau kemampuan bayar menurun akibat inflasi, maka rasio debt service ratio juga akan menurun, sehingga potensi risiko kreditnya menjadi lebih besar.

\section{LANDASAN TEORI}

\section{Teori Kredit UMKM}

Menurut Undang-Undang Republik Indonesia No. 20 Tahun 2008, tentang Usaha Mikro, Kecil dan Menengah menyebutkan bahwa:

a. Usaha Mikro adalah usaha produktif milik orang perorangan dan/atau badan usaha perorangan yang memenuhi kriteria Usaha Mikro sebagaimana diatur dalam Undang-Undang.

b. Usaha Kecil adalah usaha ekonomi produktif yang berdiri sendiri, yang dilakukan oleh orang perorangan atau badan usaha yang bukan merupakan anak perusahaan atau bukan cabang perusahaan yang dimiliki, dikuasai, atau menjadi bagian baik langsung maupun tidak langsung dari Usaha Menengah atau Usaha Besar yang memenuhi kriteria Usaha Kecil sebagaimana dimaksud dalam Undang-Undang.

c. Usaha Menengah adalah usaha ekonomi produktif yang berdiri sendiri, yang dilakukan oleh orang perorangan atau badan usaha yang bukan merupakan anak perusahaan atau cabang perusahaan yang dimiliki, dikuasai atau menjadi bagian baik langsung maupun tidak langsung dengan Usaha Kecil atau Usaha Besar dengan jumlah kekayaan bersih atau hasil penjualan tahunan sebagaimana diatur dalam Undang-Undang.

\section{Kriteria UMKM}

Kriteria UMKM, nilai nominalnya dapat diubah sesuai dengan perkembangan perekonomian yang diatur dengan Peraturan Presiden 
1. Kriteria Usaha Mikro adalah sebagai berikut:

a. Memiliki kekayaan bersih paling banyak Rp 50.000.000,00 (lima puluh juta rupiah) tidak termasuk tanah dan bangunan tempat usaha; atau

b. Memiliki hasil penjualan tahunan paling banyak Rp 300.000.000,00 (tiga ratus juta rupiah).

2. Kriteria Usaha Kecil adalah sebagai berikut:

a. Memiliki kekayaan bersih lebih dari Rp 50.000.000,00 (lima puluh juta rupiah) sampai dengan paling banyak Rp 500.000.000,00 (lima ratus juta rupiah) tidak termasuk tanah dan bangunan tempat usaha; atau

b. Memiliki hasil penjualan tahunan lebih dari Rp 300.000.000,00 (tiga ratus juta rupiah) sampai dengan paling banyak Rp 2.500.000.000,00 (dua milyar lima ratus juta rupiah).

3. Kriteria Usaha Menengah adalah sebagai berikut:

a. Memiliki kekayaan bersih lebih dari Rp 500.000.000,00 (lima ratus juta rupiah) sampai dengan paling banyak Rp10.000.000.000,00 (sepuluh milyar rupiah) tidak termasuk tanah dan bangunan tempat usaha; atau

b. Memiliki hasil penjualan tahunan lebih dari Rp 2.500.000.000,00 (dua milyar lima ratus juta rupiah) sampai dengan paling banyak $\mathrm{Rp}$ 50.000.000.000,00 (lima puluh milyar rupiah).

Pemerintah menyadari bahwa untuk mendorong, memperdayakan dan mengembangkan Usaha Mikro Kecil dan Menengah UMKM) tersebut dibutuhkan modal yang tidak sedikit, sedangkan di sisi lain pengusaha pada kategori UMKM pada umumnya tidak memiliki modal yang cukup dan sulit untuk mengakses permodalan dari lembaga perbankan, karena sebagian besar pelaku UMKM tidak memiliki jaminan, administrasi keuangan tidak tertib (tidak dibuat), belum memisahkan pencatatan antara keuangan secara pribadi dengan keuangan usaha, tidak memiliki laporan keuangan, sehingga pihak perbankan akan mengalami kesulitan dalam menilai kelayakan usahanya, sedangkan kelayakan usaha ini sangat penting dan dibutuhkan pada saat bank akan memberikan keputusan untuk memberikan bantuan pembiayaan. Jumlah UMKM yang tidak sedikit membuktikan banyaknya masyarakat yang mulai menyadari pentingnya menjadi seorang wirausaha dan di Indonesia sendiri jumlah wirausahanya baru 1,5\% dari sekitar 252 juta penduduk, di mana fenomena ini terjadi karena masih rendahnya motivasi dan minat masyarakat Indonesia (Prasetya dkk, 2019).

\section{Teori Inflasi}

Inflasi adalah sebagai kenaikan jumlah uang beredar atau kenaikan likuiditas dalam suatu perekonomian, ini mengacu pada gejala umum yang ditimbulkan oleh adanya kenaikan jumlah uang beredar yang telah menyebabkan kenaikan harga-harga. Inflasi secara singkat dapat diartikan sebagai suatu kecenderungan meningkatnya harga-harga barang dan jasa secara umum dan terusmenerus. Terdapat dua pengertian yang menjadi kunci dalam memahami inflasi. Pertama adalah "kenaikan harga secara umum". Kedua adalah "terus-menerus". Hanya kenaikan harga yang terjadi secara umum yang dapat disebut sebagai inflasi. Inflasi harus menggambarkan kenaikan harga sejumlah besar barang dan jasa yang 
dipergunakan (atau dikonsumsi) dalam suatu perekonomian. Kenaikan harga yang terjadi karena faktor musiman, misalnya, menjelang hari-hari besar (Idul Fitri, Natal \& Tahun Baru, Imlek) atau kenaikan harga sesekali saja dan yang tidak mempunyai pengaruh lanjutan, tidak dapat disebut sebagai inflasi karena kenaikan harga tersebut bukan "masalah kronis" ekonomi.

\section{Dampak Inflasi}

Kenaikan inflasi dapat mengakibatkan kenaikan harga barang dan jasa, sehingga nilai mata uang akan mengalami penurunan dan daya beli mata uang menjadi semakin lemah. Penurunan daya beli akan berdampak terhadap individu, dunia usaha dan anggaran pendapatan \& belanja Pemerintah. Laju inflasi yang tinggi akan berakibat negatif terhadap suatu perekonomian. Terdapat tiga alasan mengapa inflasi menjadi penting untuk dikendalikan agar inflasi tetap rendah dan stabil, yaitu:

a. Inflasi akan menyebabkan penurunan pendapatan riil masyarakat. Pada saat terjadi inflasi dan harga-harga meningkat, maka daya beli masyarakat akan menurun.

b. Inflasi akan menciptakan keragu-raguan bagi para pelaku ekonomi baik konsumen, investor maupun pengusaha yang akhirnya dapat menghambat pertumbuhan ekonomi.

c. Tingkat inflasi yang tinggi menyebabkan tingkat bunga domestik riil kurang kompetitif sehingga dapat memberikan peluang terjadinya tekanan pada nilai tukar rupiah

\section{Teori BI Rate}

Suku bunga acuan Bank Indonesia (BI rate) mulai diterapkan pada 2005. Dalam pemahaman publik, seolah-olah BI rate adalah suku bunga SBI, sedangkan SBI merupakan salah satu alat operasi moneter saja. BI Rate sejak 19 Agustus 2016 telah diganti dengan BI 7-Day (Reverse) Repo Rate. Bank Indonesia melakukan penguatan kerangka operasi moneter dengan mengimplementasi kan suku bunga acuan atau suku bunga kebijakan baru yaitu BI 7-Day (Reverse) Repo Rate. Cara penguatan kerangka operasi moneter demikian merupakan hal yang lazim dilakukan diberbagai bank sentral dan merupakan best practice internasional dalam pelaksanaan operasi moneter. Kerangka operasi moneter selalu disempurnakan untuk memperkuat efektivitas kebijakan dalam mencapai sasaran inflasi yang ditetapkan. Instrumen BI 7-day (Reverse) Repo Rate digunakan sebagai suku bunga kebijakan baru karena dapat secara cepat mempengaruhi pasar uang, perbankan dan sektor riil. Instrumen BI 7-Day Repo Rate memiliki hubungan yang lebih kuat ke suku bunga pasar uang, karena sifatnya transaksional atau diperdagangkan di pasar dan mendorong pendalaman pasar keuangan khususnya penggunaan instrumen repo.

Terdapat tiga dampak utama penggunaan instrumen BI 7-day (Reverse) Repo Rate sebagai suku bunga kebijakan baru, yaitu :

1. Menguatnya sinyal kebijakan moneter dengan suku bunga (Reverse) Repo Rate 7 hari sebagai acuan utama di pasar keuangan. 
2. Meningkatnya efektivitas transmisi kebijakan moneter melalui pengaruhnya pada pergerakan suku bunga pasar uang dan suku bunga perbankan.

3. Terbentuknya pasar keuangan yang lebih dalam, khususnya transaksi dan pembentukan struktur suku bunga di pasar uang antarbank (PUAB) untuk tenor 3-12 bulan.

\section{Teori Suku Bunga Pinjaman}

Bunga pada prinsipnya adalah balas jasa yang diberikan oleh pihak yang membutuhkan uang kepada pihak yang memberikan uang. Bunga dapat dilihat dari dua sisi yaitu sisi penawaran dan sisi permintaan. Bunga dari sisi penawaran merupakan pendapatan atas pemberian kredit, sehingga pemilik dana akan menggunakan dananya pada jenis investasi yang menjanjikan pembayaran bunga yang tinggi, sedangkan dari sisi permintaan, bunga adalah biaya atas pinjaman atau jumlah yang dibayarkan sebagai imbalan atas penggunaan uang yang dipinjam, atau dengan kata lain bunga merupakan harga yang dibayar atas modal. Dalam pemberian kredit sering didengar dengan istilah Suku Bunga Dasar Kredit (SBDK). SBDK digunakan sebagai dasar dalam penetapan suku bunga kredit oleh pihak bank kepada nasabah (debitur). SBDK yang diumumkan (dipublikasikan) di media masa atau media elektronik belum memperhitungkan komponen estimasi premi risiko per masing-masing debitur atau kelompok debitur yang besarnya tergantung dari penilaian bank, sehingga dengan demikian, besarnya suku bunga kredit yang dikenakan kepada debitur belum tentu sama dengan SBDK yang diumumkan oleh bank yang bersangkutan di media masa. Menurut Kasmir (2000:55) menyatakan bahwa dalam kegiatan perbankan sehari-hari ada 2 (dua) macam bunga yang diberikan kepada nasabah yaitu bunga simpanan dan bunga pinjaman.

1. Bunga simpanan, adalah bunga yang diberikan sebagai perangsang atau balas jasa kepada nasabah yang menyimpan uangnya di bank. Bunga simpanan merupakan harga yang harus dibayar bank kepada nasabah. Sebagai contoh: jasa giro, bunga tabungan dan bunga deposito.

2. Bunga pinjaman, adalah bunga yang dibebankan kepada para peminjam (debitur) atau harga harus yang dibayarkan oleh nasabah kepada bank atas pinjaman modal yang dinikmati.

Bunga yang diterima bank merupakan imbalan kepercayaan, pengorbanan waktu, risiko dan juga sebagai sewa dari uang yang diberikan bank kepada nasabahnya

\section{Kualitas Kredit}

Kualitas Kredit merupakan hasil penilaian atas faktor yang berpengaruh terhadap kondisi dan kinerja debitur. Penilaian kualitas kredit ditetapkan berdasarkan faktor penilaian terhadap prospek usaha, kinerja (performance) debitur dan kemampuan membayar debitur. Bank wajib melakukan penilaian dan penetapan kualitas aset sesuai dengan Peraturan Bank Indonesia/OJK. Dalam hal terjadi perbedaan hasil penilaian kualitas aset antara Bank dan Bank Indonesia/OJK, maka kualitas aset yang diberlakukan adalah kualitas yang ditetapkan oleh Bank Indonesia/OJK. Bank wajib menyesuaikan kualitas aset sesuai dengan penilaian kualitas yang ditetapkan oleh Bank Indonesia/OJK. Aset 
produktif adalah penyediaan dana bank untuk memperoleh penghasilan, dalam bentuk kredit, surat berharga, penempatan dana antar bank, tagihan akseptasi, tagihan atas surat berharga yang dibeli dengan janji dijual kembali (reverse repurchase agreement) tagihan derivatif, penyertaan, transaksi rekening administratif serta bentuk penyediaan dana lainnya yang dapat dipersamakan dengan itu.

Kualitas Kredit ditetapkan berdasarkan faktor penilaian sebagai berikut:

1. Kualitas Kredit ditetapkan berdasarkan analisis terhadap 3 (tiga) faktor penilaian yaitu prospek usaha, kinerja (performance) debitur dan kemampuan membayar.

2. Penetapan kualitas Kredit dilakukan dengan mempertimbangkan signifikansi dan materialitas ketiga faktor penilaian dan masing-masing komponennya, serta relevansinya terhadap karakteristik debitur yang bersangkutan.

3. Kualitas Kredit ditetapkan dalam 5 (lima) kategori yaitu Lancar, Dalam Perhatian Khusus, Kurang Lancar, Diragukan dan Macet.

4. Salah satu komponen dalam faktor penilaian prospek usaha adalah upaya yang dilakukan debitur berskala besar dan/atau berisiko tinggi dalam rangka menjaga kelestarian lingkungan hidup, yang dibuktikan dengan Analisis Mengenai Dampak Lingkungan (AMDAL).

Hal ini sejalan dengan Penjelasan Pasal 8 Undang-Undang Nomor 7 Tahun 1992 tentang Perbankan sebagaimana telah diubah dengan Undang-Undang Nomor 10 Tahun 1998, Undang-Undang Nomor 32 Tahun 2009 tentang Perlindungan dan Pengelolaan Lingkungan Hidup, dan Peraturan Pemerintah Nomor 27 Tahun 2012 tentang Ijin Lingkungan. Hasil AMDAL diperlukan oleh Bank untuk memastikan bahwa proyek yang dibiayai telah menjaga kelestarian lingkungan hidup.

\section{Non Performing Loan (NPL)}

Menurut Ismail (2009:224), kredit bermasalah yaitu suatu keadaan di mana nasabah sudah tidak sanggup membayar sebagian atau seluruh kewajibannya kepada bank seperti yang telah diperjanjikan. Setiap bank harus mampu mengelola kreditnya dengan baik dalam memberikan kredit kepada masyarakat maupun dalam pengembalian kreditnya sesuai dengan syarat dan ketentuan yang berlaku sehingga tidak menimbulkan kredit bermasalah. Non Performing Loan (NPL) adalah kredit yang menunggak melebihi 90 hari. NPL merupakan kredit dalam status kurang lancar, diragukan dan macet. Besar kecilnya risiko kredit suatu bank akan tercermin dari besar kecilnya NPL. Semakin kecil NPL maka semakin kecil pula risiko kredit yang ditanggung oleh pihak bank dan sebaliknya. Untuk memitigassi risiko tersebut, maka pihak bank sebelum memberikan kredit harus melakukan analisis terhadap kelayakan usaha dan kemampuan membayar kembali pinjamannya. Setelah kredit dicairkan, bank wajib melakukan pemantauan terhadap kebenaran penggunaan kredit dan kepatuhan debitur dalam memenuhi kewajibannya. Melakukan penanda tanganan perjanjian kredit dan pengikatan jaminan (agunan) secara sempurna dengan tujuan untuk memperkecil risiko kredit.

Rasio Nonperforming Loan Kredit UMKM yang selanjutnya disebut Rasio NPL Kredit UMKM adalah rasio antara jumlah Kredit UMKM dengan kualitas 
kurang lancar, diragukan, dan macet terhadap total Kredit UMKM. Praktisi perbankan menyepakati bahwa batas aman dari NPL suatu bank tidak boleh melebihi 5\% dan ini juga yang menjadi ketetapan Bank Indonesia/OJK. Menurut Peraturan Otoritas Jasa Keuangan No. 15/POJK.03/2017 tentang Penetapan status dan tindak lanjut pengawasan Bank Umum, disebutkn bahwa Bank dalam pengawasan intensif salah satu penyebabnya adalah apabila bank dalam kondisi rasio kredit bermasalahnya secara neto (NPL net) atau rasio pembiayaan bermasalah secara neto (NPF net) lebih dari 5\% (lima persen) dari total kredit atau total pembiayaan, dan penyelesaiannya bersifat kompleks.

\section{METODOLOGI PENELITIAN}

\section{Tempat Penelitian}

Jenis penelitian adalah kuantitatif yakni dengan menggunakan data-data Laporan Bulanan OJK khususnya Kredit UMKM dari Bank Umum (Bank Pesero, Bank Pembangunan Daerah, Bank Swasta Nasional dan Bank Campuran \& Asing) dan data kuantitatif lain yang peneliti unduh dari situs OJK dan BI, untuk dapat menghitung pengaruh Inflasi, BI rate dan Suku Bunga Kredit UMKM terhadap NPL Kredit UMKM. Penelitian menggunakan data selama periode 5 tahun yang dimulai pada awal tahun 2014 sampai dengan akhir Desember 2018.

\section{Populasi dan Sampel Penelitian}

Populasi dalam penelitian ini adalah NPL Kredit UMKM dari 115 Bank Umum (4 Bank Pesero, 63 Bank Umum Swasta Nasional, 27 Bank Pembangunan Daerah dan 27 Bank Campuran \& Asing) yang datanya telah terangkum dalam laporan bulanan OJK, Inflasi dari Laporan Bank Indonesia dan Bunga Pinjaman Kredit UMKM selama periode tahun 2014 sampai akhir tahun 2018 (Desember 2018). Pemilihan sampel dilakukan berdasarkan metode Purposive Sampling, yaitu pemilihan sampel Inflasi, BI Rate, Bunga Kredit UMKM dan NPL Kredit UMKM selama periode penelitian berdasarkan pertimbangan atau kriteria tertentu.

\section{Metode Pengumpulan Data}

Metode pengumpulan data menggunakan teknik dokumentasi yang didasarkan pada laporan bulanan yang dipublikasikan oleh OJK, Bank Indonesia dan BPS selama periode 2014 sampai 2018

\section{Metode Analisis Data}

Teknik analisis data menggunakan statistik dalam hal ini penulis menggunakan bantuan program komputer SPSS versi 25. Sebelum melakukan hipotesis dengan analisis regresi berganda terlebih dahulu dilakukan uji lolos kendala linier atau uji asumsi klasik. Bentuk hipotesis dalam penelitian ini adalah hipotesis asosiatif, yakni hipotesis yang menanyakan hubungan antara dua variable atau lebih. (Sugiyono, 2011: 106).

Pengujian Asumsi Klasik

Uji Normalitas 
Uji normalitas bertujuan untuk menguji apakah dalam model regresi, variabel pengganggu atau residual memiliki distribusi normal atau tidak. Pengujian normalitas data menggunakan uji kolmogorov-smirnov. Pedoman pengambilan keputusan menurut Santoso (2016:201):

1) Jika nilai Sig atau signifikansi atau nilai probabilitas $<0,05$ distribusi adalah tidak normal (simetris).

2) Jika nilai Sig atau signifikansi atau nilai probabilitas $>0,05$ distribusi adalah normal (simetris).

\section{Uji Heteroskedastisitas}

Dalam persamaan regresi berganda perlu diuji mengenai sama atau tidak varians residual dari observasi yang satu dengan observasi yang lain. Jika residual mempunyai varians yang sama disebut homoskedastisitas, dan jika tidak sama disebut terjadi heteoskedastisitas.

\section{Uji Autokolerasi}

Menurut Ghozali (2013:110) uji autokolerasi bertujuan untuk mengetahui apakah dalam model regresi linier ada kolerasi antara kesalahan pengganggu pada periode $\mathrm{t}$ (sebelumnya). Model regresi yang baik adalah model regresi yang bebas dari autokolerasi. Uji autokolerasi pada penelitian ini menggunakan uji DurbinWatson (DW) dengan dasar pengambilan keputusannya.

\section{Uji Hipotesis}

Uji Regresi Berganda

Regresi Linier Berganda adalah hubungan secara linear antara dua atau lebih variabel independen $(\mathrm{X})$ dengan variabel dependen $(\mathrm{Y})$. Analisis ini untuk mengetahui arah hubungan antara variabel independen dengan variabel dependen.

\section{Koefisien Korelasi}

Korelasi merupakan teknik statistik yang digunakan untuk meguji ada /tidaknya hubungan serta arah hubungan dari dua variabel atau lebih. Besar kecilnya hubungan antara dua variabel dinyatakan dalam bilangan yang disebut dengan Koefisien Korelasi. Adapun pedoman untuk memberikan interpretasi koefisien kolerasi adalah sebagai berikut (Sugiono, 2016:184):

$0,00-0,199$ kolerasi sangat rendah

$0,20-0,399$ kolerasi rendah

$0,40-0,599$ kolerasi sedang

$0,60-0,799$ kolerasi kuat

$0,80-1,000$ kolerasi sangat kuat

\section{Koefisien Determinasi $\left(\mathrm{R}^{2}\right)$}

Menurut Ghozali (2013:95) koefisien determinasi $\left(\mathrm{R}^{2}\right)$ pada intinya mengukur seberapa jauh kemampuan model dalam menerangkan variasi variabel dependen, atau untuk menunjukkan seberapa besar prosentase variasi variabel independen yang digunakan dalam model, mampu menjelaskan variabel dependen. 
Uji hipotesis t (Parsial)

Menurut Ghozali (2013:98) uji statistik $t$ pada dasarnya menunjukkan seberapa jauh pengaruh satu variabel penjelas atau independen secara individual (parsial) dalam menerangkan variabel dependen.

Menurut Santoso (2015:275-276) hipotesis (dugaan) dalam uji t adalah:

1) $\mathrm{Ho}=$ variabel independen tidak berpengaruh signifikan terhadap variabel dependen

2) $\mathrm{Hi}=$ variabel independen berpengaruh signifikan terhadap variabel dependen

Tingkat signifikansi yang digunakan adalah 95\% maka nilai a $=0,05$

Dasar pengambilan keputusan:

1) Jika t hitung $>\mathrm{t}$ tabel dan probabilitas nilai $\mathrm{t}$ atau signifikansi $<0,05$, maka Ho ditolak dan Hi diterima.

2) Jika $t$ hitung $<t$ tabel dan probabilitas nilai $t$ atau signifikansi $>0,05$, maka Ho diterima dan Hi ditolak.

Uji Hipotesis F (Keseluruhan)

Menurut Ghozali (2013:127) pengujian ini untuk melihat seberapa pengaruh variabel independen secara bersama-sama (simultan) terhadap perubahan nilai variabel dependen. Dasar pengambilan keputusan dalam uji $\mathrm{F}$ berdasarkan nilai signifikansi hasil dari output SPSS - 25:

1) Jika nilai $\mathrm{F}$ hitung $>\mathrm{F}$ tabel dan Sig $<0,05$ maka variabel independen secara bersama-sama berpengaruh signifikan terhadap variabel dependen.

2) Jika nilai $\mathrm{F}$ hitung $<\mathrm{F}$ tabel dan Sig $>0,05$ maka variabel independen secara bersama-sama berpengaruh signifikan terhadap variabel dependen.

\section{HASIL PENELITIAN DAN PEMBAHASAN}

\section{Hasil Penelitian}

Statistik Deskriptif

Menurut Sugiyono (2011:147) Statistik deskriptif adalah statistik yang digunakan untuk menganalisis data dengan cara mendeskripsikan atau menggambarkan data yang telah terkumpul sebagaimana adanya tanpa bermaksud membuat kesimpulan yang berlaku untuk umum atau generalisasi. Statistik deskriptif yang digunakan adalah nilai rata-rata (mean), standar deviasi (standard deviation), dan maksimum-minimum. 
Tabel 1.

Hasil Uji Statistik Deskriptif

\begin{tabular}{|c|c|c|c|c|c|c|c|c|c|c|c|c|}
\hline & $\mathrm{N}$ & Range & Minimum & Maximum & \multicolumn{2}{|c|}{ Mean } & $\begin{array}{c}\text { Std. } \\
\text { Deviation }\end{array}$ & Variance & \multicolumn{2}{|c|}{ Skewness } & \multicolumn{2}{|c|}{ Kurtosis } \\
\hline & Statistic & Statistic & Statistic & Statistic & Statistic & Std. Error & Statistic & Statistic & Statistic & Std. Error & Statistic & Std. Error \\
\hline Inflasi & 20 & 5,48 & 2,88 & 8,36 & 4,6280 & ,39879 & 1,78346 & 3,181 & ,888 &, 512 &,- 771 & ,992 \\
\hline BI Rate & 20 & 3,25 & 4,25 & 7,50 & 6,1125 & ,29938 & 1,33888 & 1,793 &,- 179 &, 512 & $-1,777$ & 9 \\
\hline Bunga Kredit & 20 & 2,12 & 10,82 & 12,94 & 12,1255 & ,16663 & ,74518 & ,555 &,- 485 & ,512 & $-1,304$ & 95 \\
\hline Non Performing Loan & 20 & 1,39 & 3,34 & 4,73 & 4,1695 & ,07924 &, 35436 & ,126 & -631 &, 512 & - & ,99 \\
\hline
\end{tabular}

Berdasarkan tabel 1 di atas dapat disimpulkan bahwa rata-rata NPL Kredit UMKM pada periode 2014 - 2018 yang diteliti sebesar 0,7924 dengan angka minimum sebesar 3,34 dan angka maksimum sebesar 4,73 data ini menunjukkan bahwa rata-rata NPL Kredit UMKM pada periode 2014 - 2018 sebesar 0,7924

Rata-rata Inflasi yang diproksi dengan diskresioner total akrual pada periode 2014 - 2018 yang diteliti sebesar 0,39879 dengan angka minimum sebesar 2,88 dan angka maksimum sebesar 8,36 data ini menunjukkan bahwa rata-rata Inflasi pada periode 2014 - 2018 sebesar 0,39879

Rata-rata BI Rate yang diproksi dengan diskresioner total akrual pada periode 2014 - 2018 yang diteliti sebesar 0,29938 dengan angka minimum sebesar 4,25 dan angka maksimum sebesar 7,50 data ini menunjukkan bahwa rata-rata BI Rate pada periode 2014 - 2018 sebesar 0,29938

Rata-rata Bunga Kredit UMKM yang diproksi dengan diskresioner total akrual pada periode 2014 - 2018 yang diteliti sebesar 0,74518 dengan angka minimum sebesar 10,82 dan angka maksimum sebesar 12,94 data ini menunjukkan bahwa rata-rata Bunga Kredit UMKM pada periode 2014 - 2018 sebesar 0,074518

\section{Pengujian Asumsi Klasik}

Uji Normalitas

Dengan menggunakan bantuan program SPSS 22, maka didapatkan hasil pengujian normalitas menggunakan uji Kolgomorov-smirnov adalah sebagai berikut:

\section{Tabel 2}

One-Sample Kolmogorov-Smirnov Test

\begin{tabular}{|c|c|c|c|c|c|}
\hline & & Inflasi & BI Rate & $\begin{array}{l}\text { Bunga } \\
\text { Kredit }\end{array}$ & $\begin{array}{c}\text { Non } \\
\text { Performing } \\
\text { Loan }\end{array}$ \\
\hline $\mathrm{N}$ & & 20 & 20 & 20 & 20 \\
\hline Normal & Mean & 4,6280 & 6,1125 & 12,1255 & 4,1695 \\
\hline Parameters ${ }^{a, b}$ & Std. Deviation & 1,78346 & 1,33888 & ,74518 & ,35436 \\
\hline
\end{tabular}


Jurnal Ilmiah Akuntansi Universitas Pamulang - Vol. 8, No. 2, Juli 2020 - Suharna

\begin{tabular}{ll|r|r|r|r|} 
Most Extreme & Absolute &, 245 &, 250 &, 168 &, 164 \\
Differences & Positive &, 245 &, 150 &, 137 &, 098 \\
& Negative &,- 164 &,- 250 &,- 168 &,- 164 \\
& &, 245 &, 250 &, 168 &, 164 \\
Test Statistic & &, $003^{\mathrm{C}}$ &, $002^{\mathrm{C}}$ &, $143^{\mathrm{C}}$ &, $161^{\mathrm{C}}$ \\
\hline
\end{tabular}

a. Test distribution is Normal.

b. Calculated from data.

c. Lilliefors Significance Correction.

Dari tabel 2 diatas dapat dilihat bahwa nilai Asymp. Sig (2-tailed) sebesar 0,161. Syarat untuk uji kolmogorov-smirnov adalah data berdistribusi normal apabila nilai Asymp.Sig. (2-tailed) > 0,05. Maka dapat disimpulkan bahwa data dalam penelitian ini berdistribusi normal.

Uji Multikolinieritas

Pendeteksian multikolonieritas dilakukan dengan menggunakan Tolerance Value dan Variance Inflation Factor (VIF).

Tabel 3.

Hasil Uji Multikolinieritas

Coefficientsa

\begin{tabular}{|c|c|c|c|c|c|c|c|}
\hline \multirow[b]{2}{*}{ Model } & \multicolumn{2}{|c|}{$\begin{array}{l}\text { Unstandardize } \\
\text { d Coefficients }\end{array}$} & \multirow{2}{*}{$\begin{array}{c}\text { Standardized } \\
\text { Coefficients } \\
\\
\text { Beta } \\
\end{array}$} & \multirow[b]{2}{*}{$t$} & \multirow[b]{2}{*}{ Sig. } & \multicolumn{2}{|c|}{$\begin{array}{c}\text { Collinearity } \\
\text { Statistics }\end{array}$} \\
\hline & $\mathrm{B}$ & $\begin{array}{c}\text { Std. } \\
\text { Error }\end{array}$ & & & & Tolerance & VIF \\
\hline (Constant) & ,589 & 1,548 & & ,380 & ,709 & & \\
\hline Inflasi (X1) &,- 023 & ,059 &,- 115 &,- 390 & ,702 &, 450 & 2,222 \\
\hline BI Rate (X2) &,- 237 & ,090 &,- 897 & $-2,648$ & ,018 &, 341 & 2,933 \\
\hline Bunga Kredit (X3) & ,424 &, 157 & ,891 & 2,696 & ,016 &, 358 & 2,796 \\
\hline
\end{tabular}

a. Dependent Variable: Non Performing Loan

Dari tabel 3 menunjukkan bahwa nilai VIF dibawah 10 berdasarkan hasil perhitungan melalui program SPSS 25 diperoleh nilai VIF yaitu variabel Inflasi (X1) sebesar 2,222, BI Rate (X2) sebesar 2,933 dan Bunga Kredit UMKM (X3) sebesar 2,796 dengan demikian variabel tersebut terbebas dari gejala multikolinearitas, karena nilainya di bawah 10 . 
Uji Heteroskedastisitas

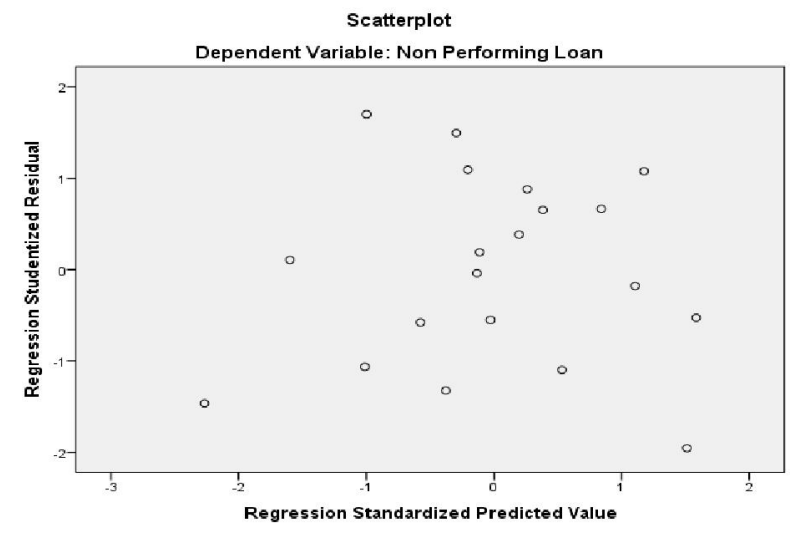

Gambar 1.

Hasil Uji Heteroskedastisitas dengan Scatter Plot

Dari hasil uji Heteroskedastisitas menggunakan grafik Scatterplot sebagaimana diatas dapat dilihat bahwa titik-titik pada gambar 4.4 menyebar secara acak, tidak memperlihatkan sebuah pola tertentu. Hal ini menunjukkan bahwa model regresi dalam penelitian ini bebas dari Heteroskedastisitas, sehingga model regresi yang baik dan ideal dapat terpenuhi.

Uji Autokolerasi

Tabel 3.

Hasil Uji Autokolerasi Durbin-Watson

Model Summary

\begin{tabular}{|c|c|r|r|r|r|}
\hline $\begin{array}{c}\text { Mode } \\
\mathrm{l}\end{array}$ & $\mathrm{R}$ & $\begin{array}{c}\mathrm{R} \\
\text { Square }\end{array}$ & $\begin{array}{c}\text { Adjusted R } \\
\text { Square }\end{array}$ & $\begin{array}{c}\text { Std. Error of } \\
\text { the Estimate }\end{array}$ & $\begin{array}{c}\text { Durbin- } \\
\text { Watson }\end{array}$ \\
\hline 1 &, $612^{\mathrm{a}}$ &, 375 &, 258 &, 30530 & 1,702 \\
\hline
\end{tabular}

a. Predictors: (Constant), Bunga Kredit, Inflasi, BI Rate

b. Dependent Variable: Non Performing Loan

Berdasarkan tabel output "Model Summary" di atas, diketahui bahwa nilai Durbin-Watson (d) adalah 1,702 lebih besar dari batas atas (du) yakni sebesar 1,6763 dan kurang dari (4-du) $4-1,6763=2.3237$ maka sebagaimana dasar pengambilan keputusan dalam uji Durbin-Watson diatas, dapat disimpulkan bahwa tidak terdapat masalah atau gejala autokorelasi, dengan demikian maka penelitian ini dapat dilanjutkan

Pengujian Hipotesis

Uji Regresi Berganda

Dari tabel $2 \mathrm{~d}$ iatas didapatkan persamaan regresinya adalah sebagai berikut: $\mathrm{Y}=\mathrm{a}+\mathrm{b} 1 \mathrm{x} 1+\mathrm{b} 2 \times 2+\mathrm{b} 3 \times 3$ atau 
$\mathrm{Y}=0,589-0,023-0,237+0,424$

1) Konstan sebesar 0,589, artinya apabila variabel Inflasi, BI Rate dan Suku bunga kredit UMKM bernilai sama dengan nol atau tidak ada, maka Non Performing Loan (NPL) Kredit UMKM akan bernilai positif 0,0589.

2) Koefisien regresi $X 1$ atau Inflasi bernilai - 0,023 menyatakan bahwa setiap penambahan 1 satuan Inflasi akan meningkatkan NPL Kredit UMKM sebesar 0,023 .

3) Koefisien regresi $\mathrm{X} 2$ atau BI Rate bernilai -0,237 menyatakan bahwa setiap penambahan 1 satuan BI Rate maka NPL Kredit UMKM akan turun sebesar 0,237 .

4) Koefisien regresi X3 atau Suku Bunga Kredit UMKM bernilai -0,424 menyatakan bahwa setiap penambahan 1 satuan Suku Bunga Kredit UMKM maka NPL Kredit UMKM akan turun sebesar 0,424

\section{Koefisien Korelasi}

Berdasarkan tabel 3 diketahui nilai koefisien determinasi atau R Square adalah sebesar 0,375 . Nilai $R$ Square 0,375 berasal dari penguadratan nilai koefisien korelasi atau "R" yaitu 0,612 x $0,612=0,375$. Besarnya angka koefisien determinasi ( $R$ Square) adalah 0,612 atau sama dengan 61,2\%. Angka tersebut mengandung arti bahwa variabel Inflasi (X1), BI Rate (X2) dan Bunga Kredit UMKM (X3) secara simultan (bersama-sama) berpengaruh terhadap variabel Non Performing Loan (Y) sebesar 61,2\%, sedangkan sisanya $(100 \%-61,2 \%=38,8 \%)$ dipengaruhi oleh variabel lain diluar persamaan regresi ini atau variabel yang tidak diteliti.

\section{Uji Pengaruh Parsial (uji t)}

Berdasarkan tabel 2 menunjukan bahwa ada pengaruh Inflasi, BI Rate dan Bunga Kredit UMKM terhadap Non Performing Loan (NPL) Kredit UMKM. Berikut ini akan dijelaskan mengenai uji signifikan parameter individual (uji statistik t) yaitu sebagai berikut:

a. Uji Hipotesis 1 (Inflasi)

Berdasarkan tabel coefficients di atas, diperoleh nilai $\mathrm{t}$ hitung untuk variabel Inflasi (X1) sebesar -0,390 sedangkan nilai $t$ tabel untuk $\mathrm{N}=20$ sebesar 2,086. Jadi $-0,390<2,086$ dengan nilai signifikan sebesar 0,702 >0,05, maka H0 diterima dan Ha ditolak, dapat dinyatakan bahwa Inflasi (X1) berpengaruh negatif dan signifikan terhadap Non Performing Loan Kredit UMKM (Y).

b. Uji Hipotesis 2 (BI Rate)

Berdasarkan tabel coefficients di atas, diperoleh nilai t hitung untuk variabel BI Rate (X2) sebesar -2,648 sedangkan nilai $t$ tabel untuk $N=20$ sebesar 2,086. Jadi 2,648 > 2,086 dengan nilai signifikan sebesar 0,018<0,05, maka H0 ditolak dan Ha diterima, dapat dinyatakan bahwa BI Rate (X2) berpengaruh positif dan signifikan terhadap Non Performing Loan Kredit UMKM (Y). Jadi dapat 
disimpulkan bahwa BI Rate dapat mempengaruhi keputusan manajemen terhadap NPL.

c. Uji Hipotesis 3 (Bunga Kredit UMKM)

Berdasarkan tabel coefficients di atas, diperoleh nilai t hitung untuk variabel Bunga Kredit UMKM (X3) sebesar 2,696 sedangkan nilai t tabel untuk N =20 sebesar 2,086. Jadi 2,696 > 2,086 dengan nilai signifikan sebesar 0,016 <0,05, maka H0 ditolak dan Ha diterima, dapat dinyatakan bahwa Bunga Kredit UMKM (X3) berpengaruh positif dan signifikan terhadap Non Performing Loan Kredit UMKM (Y). Dengan adanya peningkatan bunga pinjaman, maka jumlah angsuran/kewajiban debitur akan bertambah. Jika pendapatan nasabah tidak bertambah sedangkan disisi lain total kewajiban bertambah akibat peningkatan bunga pinjaman maka rasio kemampuan bayar (debt service ratio) debitur semakin menurun akibatnya potensi risiko kreditnya menjadi meningkat

\section{Uji Koefisiensi Deter minasi (R2)}

Untuk mengetahui seberapa besar persentase variasi-variabel independen Inflasi, BI Rate dan Bunga Kredit UMKM yang digunakan dalam model mampu menjelaskan variabel dependen Non Performing Loan (NPL) Kredit UMKM. Dari tabel 3 diatas diketahui bahwa koefisien determinasi yang disesuaikan (Adjusted $R$ Square) sebesar 0,258 atau sebesar 25,8 \%. Hal ini berarti $25,8 \%$ dari variabel dependen yaitu NPL bisa dijelaskan oleh variabel independen Inflasi, BI Rate dan Bunga Kredit UMKM. Sedangkan sisanya sebesar 74,2 \% dijelaskan oleh variabel lain yang tidak diteliti dalam penelitian ini.

\section{Uji Pengaruh Simultan (uji F)}

Uji Hipotesis F (keseluruhan) menunjukkan apakah semua variabel bebas Inflasi, BI Rate dan Bunga Kredit UMKM secara simultan mempunyai pengaruh terhadap variabel terikat NPL.

\section{Tabel 4. Hasil Uji Hipotesis F} ANOVA

\begin{tabular}{l|r|r|r|r|r|}
\hline \multicolumn{1}{|l|}{ Model } & Sum of Squares & df & Mean Square & F & Sig. \\
\hline $1 \quad$ Regression &, 895 & 3 &, 298 & 3,199 &, $052^{\mathrm{b}}$ \\
Residual & 1,491 & 16 &, 093 & & \\
Total & 2,386 & 19 & & & \\
\hline
\end{tabular}
a. Dependent Variable: Non Performing Loan
b. Predictors: (Constant), Bunga Kredit, Inflasi, BI Rate

Dari hasil analisis pada tabel di atas yakni uji ANOVA diperoleh nilai Fhitung sebesar 3,199. Sedang Ftabel $($ a 0,05) untuk $N=20$ adalah sebesar 3,20. Jadi Fhitung $=$ dari $F$ tabel atau 3,199 pembulatan menjadi 3,2 dengan nilai signifikan sebesar 0,052, maka dapat dikatakan bahwa Inflasi (X1), BI Rate (X2) dan Bunga Kredit UMKM 
Jurnal Ilmiah Akuntansi Universitas Pamulang - Vol. 8, No. 2, Juli 2020 - Suharna

(X3) memiliki pengaruh secara bersama-sama terhadap Non Performing Loan Kredit UMKM (Variabel Y) pada Bank Umum pada periode 2014 - 2018.

Pembahasan

Pengaruh Inflasi terjadap NPL

Hasil dari pengujian untuk Inflasi yaitu t hitung $<\mathrm{t}$ tabel yaitu $(-0,390<2,086)$ dan mempunyai angka signifikansi 0,702 sehingga nilai tersebut lebih besar dari 0,050, Ini berarti bahwa Inflasi tidak berpengaruh terhadap NPL, dengan demikian bahwa H1 ditolak. Hal ini konsisten dengan hasil penelitian yang dilakukan Hermawan Soebagia (2005), Muthia, Roza Linda, Megawati dan Definawati (2008) dan Risky Indrawan (2013). Hasil di atas menunjukkan bahwa pada kondisi Inflasi yang tinggi cenderung akan menurunkan kemampuan membayar.

Pengaruh BI Rate terhadap NPL

Hasil pengujian untuk BI Rate yaitu $\mathrm{t}$ hitung $>\mathrm{t}$ tabel yaitu $(2,648<2,086)$ dan mempunyai angka signifikansi 0,018 sehingga nilai tersebut lebih kecil dari 0,050, ini berarti BI Rate berpengaruh negatif dan signifikan terhadap NPL. Dengan demikian bahwa $\mathrm{H} 2$ diterima.

Pengaruh Bunga Pinjaman terhadap NPL Kredit UMKM

Hasil pengujian untuk Bunga Kredit UMKM yaitu t hitung > t tabel yaitu (2,696> 2,086) dan mempunyai angka signifikansi 0,16 sehingga nilai tersebut lebih besar dari 0,050, ini berarti Bunga Kredit UMKM berpengaruh signifikan terhadap NPL. Dengan demikian bahwa $\mathrm{H} 3$ diterima

\section{KESIMPULAN}

Berdasarkan hasil dari analisis data dan pembahasan yang telah dijelaskan, maka kesimpulan yang dapat diambil dari penelitian ini adalah pengaruh variabel independen Inflasi, BI Rate dan Suku Bunga UMKM terhadap Non Performing Loan (NPL) baik secara simultan maupun secara parsial. Berikut hasil penelitian yang diperoleh dalam penelitian ini adalah:

1. Berdasarkan hasil penelitian ini Inflasi berpengaruh terhadap NPL dengan t hitung < t tabel yaitu $(-0,390<2,086)$ dan mempunyai angka signifikansi 0,702 sehingga nilai tersebut lebih besar dari 0,050 .

2. Berdasarkan tabel coefficients di atas, diperoleh nilai t hitung untuk variabel BI Rate (X2) sebesar -2,648 sedangkan nilai t tabel untuk $\mathrm{N}=20$ sebesar 2,086. Jadi 2,648 > 2,086 dengan nilai signifikan sebesar 0,018<0,05, maka H0 ditolak dan Ha diterima, dapat dinyatakan bahwa BI Rate (X2) berpengaruh positif dan signifikan terhadap Non Performing Loan Kredit $\operatorname{UMKM}(\mathrm{Y})$.

3. Berdasarkan hasil penelitian Bunga Kredit UMKM berpengaruh terhadap NPL, dengan t hitung sebesar 2,696 > nilai t tabel 2,086.dan nilai signifikan sebesar $0,016<0,05$. 
4. Berdasarkan hasil penelitian ini variabel Inflasi, BI Rate dan Bunga Pinjaman Kredit UMKM secara simultan berpengaruh terhadap peningkatan NPL.

\section{DAFTAR PUSTAKA}

Bank Indonesia, PBI Nomor 14/22/PBI/2012 tentang Pemberian Kredit atau Pembiayaan oleh Bank Umum dan Bantuan Teknis dalam rangka Pengembangan Usaha Mikro, Kecil, dan Menengah

----, LAPORAN INFLASI (Indeks Harga Konsumen) berdasarkan perhitungan inflasi tahunan

-----, BI Rate (BI 7-day -Reverse (Repo Rate)

-----, Inflasi, Suseno dan Siti Astiyah, Pusat Pendidikan Dan Studi Kebanksentralan (PPSK), Maret 2009

Dr. Hendy Herijanto, SE, MBA, MH, 2012, Selamatkan Perbankan Demi Perekonomian Indonesia

Ghozali, Imam. (2007). Manajemen Risiko Perbankan. Semarang: BP-UNDI

Gregorius Agung, SPSS Komplit untuk Mahasiswa, Tutorial komprehensif untuk memahami SPSS bagi para mahasiswa, Jublee Emterprise, Penerbit PT Elex Media Komputindo tahun 2018

Hermawan Soebagia (2005), Analisis faktor-faktor yang mempengaruhi NPL pada Bank Umum Komersial

Kasmir. 2013. Bank dan Lembaga Keuangan Lainnya. Jakarta: PT. Raja Grafindo Persada.

Muthia Roza Linda, Megawati, Definawati (2008), Pengaruh Inflasi, Kurs dan Tingkat Bunga Terhadap Non Performing Loan Pada PT. Bank Tabungan Negara (Pesero) Tbk Cabang Padang

Otoritas Jasa Keuangan SE no 34 /SEOJK.03/2017 tentang Transparansi Informasi Suku Bunga Dasar Kredit

\section{-----, Statistik Perbankan Indonesia M ei 2019}

-----, Peraturan Otoritas Jasa Keuangan No. 15/ POJK.03/ 2017 tentang Penetapan status dan tindak lanjut pengawasan Bank Umum

Prasetya, E. R., Mundiroh, S., Marpitasa, S., \& Sadewa, P. (2019). Pengaruh Pendekatan Pembelajaran Bahasa Inggris Dan Berhitung Berbasis Kewirausahaan Terhadap Peningkatan Minat Berwirausaha Bagi Anak Panti Asuhan Al Kamilah. Abdimisi, 1(1), 1-9.

Risky Indrawan (2013), Analisis Pengaruh LDR, SBI, Bank Size dan Inflasi terhadap Non Performing Loan Kredit Kepemilikan Rumah 
Jurnal Ilmiah Akuntansi Universitas Pamulang - Vol. 8, No. 2, Juli 2020 - Suharna

Suharno, SE, MM. (2003). Analisa Kredit, Penerbit Djambatan Jakarta

Undang-Undang Republik Indonesia No 20 Tahun 2008, tentang Usaha Mikro, Kecil dan Menengah

Yesica Yulian Adicondro, Irene Rini Demi Pangestu. (2015). Analisis Pengaruh Pertumbuhan GDP, Tingkat Suku Bunga, Pertumbungan Ekspor, Pertumbuhan Kredit dan BOPO terhadap NPL pada Bank Umum di Indonesia tahun $2010-2014$ 